\title{
Board Independence as an Antecedent for Firm Performance in the Context of Deposit Taking Savings and Credit Co-Operative Societies in Nairobi City County, Kenya
}

\author{
Zephaniah C. Chesire*, Dr Godfrey Kinyua \\ School of Business, Kenyatta University, Nairobi, Kenya
}

*Corresponding Authors: Zephaniah C. Chesire, School of Business, Kenyatta University, Nairobi, Kenya

\begin{abstract}
In Kenya, the deposit taking savings and credit societies segment of the Kenyan SACCO subsector is vital for the growth of the developing economy in playing a distinct and important role of providing financial services. However, DTSs' performance has been dwindling with members seeking financial services from SACCOS in Kenya declining from 13.5\% in the year 2009 to $9.1 \%$ in the year 2015. Most of them are providing for potential bad loans in their books of accounts raising questions over their fitness in the key credit market. Despite the contribution to the economy, DTSs continue to experience huge losses with others even collapsing questioning the measures put in place in ensuring continued performance. This study therefore, aimed at determining the effect of board independence on performance of deposit taking SACCOs in Nairobi City County, Kenya. Descriptive cross-sectional survey was adopted by the study. Target population comprised staff at the managerial level employed at the head offices of licensed deposit taking savings and credit societies in Nairobi City County, Kenya who were selected using census sampling. The study used both primary and secondary data in obtaining information. The primary data was obtained by the use of semi-questionnaires. Descriptive statistics were used to provide summary measures of data observed and include frequencies, percentages, mean, coefficient of variation and standard deviation. Inferential statistics was conducted using correlation and simple linear regression analysis. Research findings were presented in form of graphs, charts, tables and descriptive statistics. The findings on the correlation analysis showed that board independence had Pearson correlation of 0.333. The study therefore concludes that maintenance of a well-functioning, balanced and diverse board is a main determinant of organizational performance. The study also recommends that a governance code or policy be developed for the SACCOs as it is better aligned to co-operative principles. Additionally, the study recommends that the companies should conduct frequent monitoring and evaluation of the boards put in place so as to maximize their potentials
\end{abstract}

Key words: Board Independence, Deposit Taking Savings and Credit Co-Operative Societies

\section{INTRODUCTION AND BACKGROUND}

Performance is crucial in increasing the firm worth and boosting the growth of the entire industry thus leading to economic growth and development. A firm's performance is determined by the returns accrued when the year ends in comparison to the start of the year (Mwangi, \& Birundu, 2015). It is assessed by the effectiveness of resources management based on the prevailing external environment in line with the firm's strategic goals.

A sound financial performance thus enables firms to manage the risks faced by the organization including solvency, liquidity problems, market fluctuation and creditworthiness of the customers (Ahsan, 2016). This acts as an appraisal of efficiency, accountability, productivity and preparedness of the entity within a particular timeframe. However, globally, financial scandals have been witnessed with most organizations showing dismal performance proving that it has become more difficult for most organizations to remain profitable (Mbaire, 2017). A study conducted by Lincolin, (2015) revealed that Deposit Taking Savings and Credit Societies (DTSs) continue to underperform due to poor governance mechanisms.

In developed countries such as Canada and Europe Credit unions continue to perform dismally due to challenges in administration, governance and accountability (Iyikirenga, 2014). This implies that most DTSs are not retaining sufficient earnings to build capital, proportionately to the growth of their asset 
base. Financial institutions including DTSs are faced with an array of challenges leading to some being declared insolvent (Duncan, Njeru, \& Tirimba, 2015).

Regionally, Deposit Taking SACCOs (DTS) continue to experience credit, interest, liquidity and operational risks which threaten their survival (Ogega, 2014). Studies conducted in Ethiopia, Zambia and Tanzania have revealed that these challenges hinder the exploitation of the full potential of DTSs leading to poor performance (Magali, \& Lang'at, 2014). While a study conducted in Rwanda revealed that DTSs have come under spotlight for cases of mismanagement and a number of them have been liquidated (Muvuna, 2017). Inadequate managerial policies for risk mitigation have been also established to negatively affect the profitability and financial stability of the DTSs (Elyasiani, \& Jia, 2019).

In Kenya, the contribution of financial institutions towards financial inclusion and access cannot be ignored because of their support in financial resources allocation to other sectors of the economy (Anyanga, \& Rotich, 2017). However, in spite of their growth in the past ten years, deposit taking savings and credit societies are faced with various challenges which limit their expansion which mainly occur as a result of poor governance and mismanagements (Njenga, \& Jagongo, 2019). Challenges bedeviling deposit taking savings and credit societies include improper regulations, lack of separation of ownership, inadequate experience in the management as well as lack of accountability of the board members which reduce their financial performance (Omwenga, 2019).

According to OECD, (2014) performance may entail an organization's success in achieving its set goals and targets through strong governance and sound management. Performance may also be termed as the rate and efficiency at which operations are undertaken in the organization. The initiative to measure the performance of a firm assists organization to mitigate against factors that may prevent it from achieving its mission and offer certainty. There is no standard measurement of an organization's performance due to the varied opinion on the theoretical and practice assessment of a well performing entity (Mensah, \& Maponga, 2017).

Hargovan, and Harris, (2018) term Corporate Governance (CG) as practices done in ensuring that there is alignment of interests of stakeholders, employees and investors in capital maximisation. Similarly, Kenani, and Bett, (2018) term corporate governance as procedures geared at directing and management of the affairs of an organization in an orderly manner so as to foster transparency and accountability. Good CG practices ensure that businesses are managed properly and return on investment to the investors is fair as observed by (Karuma, 2017).

The aims of CG is to ensure that there is accountability among the corporate managers in enhancing proper management of the corporate and financial performance through proper organization control (Barako, \& Brown, 2016). However, ineffective corporate governance may result in mismanagements of funds, corruptions, waste mismanagement, loss of employees and customers' trust, nepotism, and even insolvency of the organization. The corporate scandals witnessed in the recent past lead to increased demand for more accountability and responsiveness both to the Management and owners (Johnson, schools \& Whittington, 2014).

Deposit taking SACCOs are financial organizations which are started and operated on basis of promotion of the financial wellness of its members (Anyanga, \& Rotich, 2017). Introduction of SACCOs was started early 1960s and later increased greatly since then. By the end of year 2016, the number had risen even higher to over 7 million members (CMA, 2017), indicating an immerse increase in popularity of SACCOs among the people. SACCO Societies Regulatory Authority (SASRA) has been given the mandate of regulation of these SACCOs with a total of 177 DTS being licensed by 2017.

The co-operatives have in the past successfully provided financial services to many sectors of the Kenya economy including salaried employees and Jua Kali artisans (Oseno, 2019). SACCOs therefore offers similar products as banks. Their growth in customer base, market share and expansion level is not substantial as compared to banks. This performance and growth in those terms also varies among different SACCOs. Though there also has been tremendous growth witnessed over the years with some societies expanding to deposit taking services and running Front Office Services Activities (FOSA), effective corporate governance practices are yet to be fully attained. 


\section{Statement of the Problem}

In Kenya, the deposit taking SACCOs segment of the Kenyan SACCO subsector is vital for the growth of the developing economy in playing a distinct and important role of providing financial services (Mumanyi, 2014; Duncan, Njeru, \& Tirimba, 2015). However, the DTS performance has been dwindling with members seeking financial services from SACCOS in Kenya declining from $13.5 \%$ in the year 2009 to $9.1 \%$ in the year 2015 (Kiragu, 2015). More than 100 deposit-taking SACCOs did not meet the mandatory capital adequacy requirement in 2016 and $22 \%$ increase in loan loss allowance implying that more and more are providing for potential bad loans in their books of accounts raising questions over their fitness in the key credit market (SASRA, 2017).

Despite the contribution to Kenyan economy, DTSs continue to experience huge losses with others even collapsing questioning the measures put in place in ensuring continued performance (Oseno, 2019). Similarly, most of the DTSs in developing have been riddled with financial scandals and management related challenges leading to dismal performance. This concurs with Ammar, (2017) who studied performance of Sudanese Microfinance Sector. While Keben, and Maina, (2018) found that more than $40 \%$ DTS located in Uasin Gishu continue to face diminished performance.

The literature reviewed though supports that majority of DTS continue to struggle in performing, most of the empirical studies undertaken have concentrated mainly commercial banks. Moreover, the studies conducted have established contradicting findings on the effects of CG it has on the firm performance. Subsequently, a number of the studies reviewed concentrated on financial performance as opposed to non-financial performance which the study intends to focus on. The study to determine the effect of board independence on performance of deposits SACCOs in Nairobi City County, Kenya.

\section{LITERATURE REVIEW}

\subsection{Stewardship Theory}

The study was guided by Stewardship Theory. The theory was pioneered by David and Donaldson, (1993) and further advanced in explain management in organizations. The theory postulates it's the core aim of managers in maximizing the performance of organizations in attempts of ensuring prosperity and growth. The interests of the managers are therefore purely oriented in accomplishment of the organizational goals and not their self-interests. The importance of the theory is that it incorporates the concept of accountability among the stakeholders (Otieno et al, 2015).

A key assumption made by the theory is that there is harmonization between the stakeholders, managers and owners. The proposition of the theory to the study is that stewards constitute a crucial component of performance of entities. A main focus of the theory is that decisions made by the corporate board take into consideration the intrinsic interests of the stewards. The stewards' interests are also assumed to over-ride all other interest that may deter profit maximization and improvement of performance. The theory was utilized in describing the influence of size and independence of the board on how DTSs perform.

\subsection{Empirical Literature Review}

\subsubsection{Board Independence and Performance}

Ogega (2010) studied CG and performance of NSE listed firms in the financial sector. The independent variables were board independence, board governance disclosure, shareholding compensation, shareholder's rights and corporate governance index. Key finding of the study was that board governance disclosure positively affected performance. The study was however limited to the listed institutions in NSE leaving out the DTSs which will be investigated by the study.

Oketch, Kilika, \& Kinyua, (2020) conducted a study on the effect of top management team cognitive characteristics on organizational performance of independent regulatory agencies in Kenya. Primary data was collected using structured questionnaire comprising of closed ended questions. Descriptive and inferential statistics were then used to analyze the prepared data. From the findings the study concluded that top management team cognitive cognitive characteristics significantly affects organizational performance of the independent regulatory agencies. 
Kakabadse, Yang and Sanders (2010) analyzed the extent to which independent member functions were effective in Chinese firms. The study was conducted using interviews and established that the CG system of the state owned enterprises was still lacking. Board independence was also establishing to negatively affect performance. As such the board member were concluded to have difficulties in remaining independent which prevented them to adequately control and monitor the management.

Ombaba, (2018) investigated CG practices among SACCOs guided by the credit risk theory. Purposive technique was used in sampling of the respondents. The study concluded a positive association between risk management and corporate governance. Similar results were obtained by Matanda, (2016) on a study focusing on commercial banks in Kenya. The study however may not be equally compared to deposit taking SACCOs.

Mbai, Kinyua \& Muhoho (2018) conducted a study to investigate the effect of board leadership on performance of Machakos Water and Sewerage Company in Kenya. Primary data was collected using structured questionnaire whereas secondary data was obtained through a review of relevant published reports in order to validate the data collected from the field. The research instrument was administered through the drop and pick method with an object of enhancing the response rate. The findings of study revealed that corporate leadership has a positive contribution to the overall performance of the company.

\subsection{Conceptual Framework}

Independent Variable

\section{Dependent Variable}

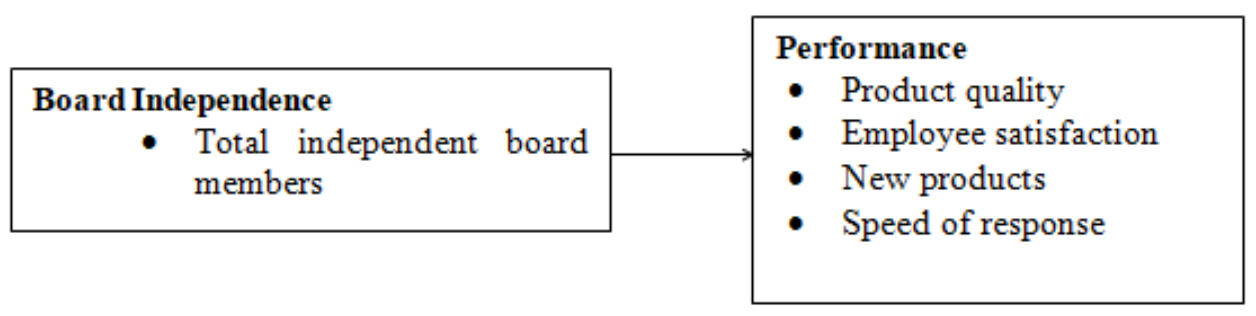

Figure1. Conceptual Framework

\section{RESEARCH METHODOLOGY}

A research design is viewed as a conceptual model within which research is conducted and contains a blueprint for measurement and analysis of observed data (Kothari, 2004; Kitur \& Kinyua, 2020; Mbugua \& Kinyua, 2020; Mugambi \& Kinyua, 2020; Ong'esa \& Kinyua, 2020; Wanjiku, Kinyua \& Kahuthia 2020; Murerwa \& Kinyua, 2021).This study used the descriptive cross-sectional survey. This design is concerned with establishing the way things are and thus aids in determination of the current nature of a phenomenon under study (Cooper \& Schindler, 2012). The research design incorporates quantitative as well as qualitative approaches in establishing the underlying phenomenon. This is through gathering of required data in description of events, practices and activities therefore appropriate for the study. Unit of analysis for the study was Nairobi based deposit taking SACCOs and target population were top managerial employees in the firms. The research design further enabled the analysis of the data collection using both inferential and descriptive statistics.

All the 177 registered deposit SACCOs in Kenya formed the population for this study (SASRA, 2017). As such the 35 licensed DTSs in Nairobi City County, Kenya formed the study target population as per appendix I. This target population was selected because of its proximity to the researcher and thus the most convenient for conducting the study on. The sample to be used in the study was selected using a census sampling approach so as to encompass all the 35 licensed DTSs. Census sampling approach entailed a complete enumeration of all items in a population (Lohr, 2019). The use of census sampling approach is recommended where the study population is small and manageable hence facilitate equal representation of the study elements (Creswell \& Creswell, 2017). Census sampling is recommended where the entire group is to be used to enable comprehensive determination of the phenomena under study where variability within the population is high. The sample size of the 35 licensed deposit taking SACCOs therefore enabled large amount of data to be 
collected from an ideal population and in a highly economical way. This maximized reliability of the data collected and also responding adequately to the objectives of the problem being studied while conforming to time, resources and skills availability of the researcher. The study targeted 3 respondents from each firm comprised which comprised of the head of finance, head of operations and director or their equivalents which made a total of 105 respondents. This study used both primary and secondary data. The primary data was obtained from the research questionnaire. The questionnaires were structured into sections each section addressing the study variables on a 5-point Likert Scale. Secondary data on the other hand was collected for a period of 5 years (2015-2019). This related to the information pertaining to the financial performance of the DTS. The secondary data were collected using data collection sheets and were collected from the annually published commercial banks' financial statements

Transmittal letter obtained from Kenyatta University was used to process permit from the National Council of Science, Technology and innovation (NACOSTI). The research permit and transmittal letter were used to secure appointment with the management and target respondents of DTS. Administration of the questionnaires of the questionnaires was done through a drop and pick method to give the respondents ample time to fully complete the questionnaires and ensure a high response rate. Follow ups were then done using calls and emails to the respondents. The process continued until a reasonable number of questionnaires were collected. The collected questionnaires were then tracked using a register.

A pilot study was conducted with twenty respondents who were selected from the target population. The employees who were involved in the pilot test were excluded from the sample to be selected for the final research. This was done to ensure that the study instruments met the validity and reliability test.The instrument was evaluated for content, construct and face validity. Content validity was achieved by ensuring that the questionnaire had proper vocabulary, structure and relevancy. Coherence and accuracy of data collection tools and daily cleaning of data was also ensured. Construct validity was achieved from literature review and aligning the data collection instruments (Heale, \& Twycross, 2015). Face validity further ensured validity of questionnaire based on respondent's attitude and opinions and multiple choice questions with adequate opinions were used.Reliability refers the nature of consistency of the data obtained by the research instruments (Mugenda \& Mugenda, 2008). A pilot study was conducted and pretesting of questionnaires was done for reliability and rectifying inconsistencies that may arise.

Data collected was sorted, classified, coded into coding sheets and analyzed with the aid of SPPS Version 22. Measures of central tendencies including means, frequencies and standard deviations were utilized in calculation of the summarized quantitative data. In analyzing open ended questions, content analysis method was used. The results were presented using figures and tables. Inferential statistics made the use of simple linear regression analysis as shown in model 1 in establishing the relationship between the study variables.

$\mathbf{Y}=\beta_{0}+\beta_{1} \mathbf{X}_{1+} \varepsilon$ Model 1.

Where,

$\mathrm{Y}=$ Performance

$\mathrm{X}_{1}=$ Board independence

\section{RESUlTS AND DISCUSSIONS}

The study targeted managerial employees at the licensed DTSs in Nairobi City County, Kenya. The study attained a response rate of $78 \%$

\subsection{Age of the Respondents}

This section sought at establish the respondents age. The results obtained are shown by Table 4.1.

Table4.1. Age of the Respondents

\begin{tabular}{|l|l|l|}
\hline Age & Percentage & Frequency \\
\hline $18-24$ years & 5 & $6 \%$ \\
\hline $25-34$ years & 11 & $13 \%$ \\
\hline
\end{tabular}


Board Independence as an Antecedent for Firm Performance in the Context of Deposit Taking Savings and Credit Co-Operative Societies in Nairobi City County, Kenya

\begin{tabular}{|l|l|l|}
\hline $35-44$ years & 24 & $29 \%$ \\
\hline $45-54$ years & 20 & $24 \%$ \\
\hline Above 55 years & 22 & $27 \%$ \\
\hline Total & $\mathbf{8 2}$ & $\mathbf{1 0 0 \%}$ \\
\hline
\end{tabular}

\section{Source; Research Findings 2020}

As shown, $29 \%$ of the respondents were between 35 to 44 years, $27 \%$ of the respondents were above 55 years, $24 \%$ between 45 to 54 years, $13 \%$ between $25-34$ years and the remaining $6 \%$ between 18 to 24 years. This implies that majority of the respondents $(51 \%)$ were above 45 years hence were able to provide mature and well thought after responses.

\subsection{Work department of the Respondents}

This section aimed at determining the department of the employees worked under. The results are presented in Figure 4.1

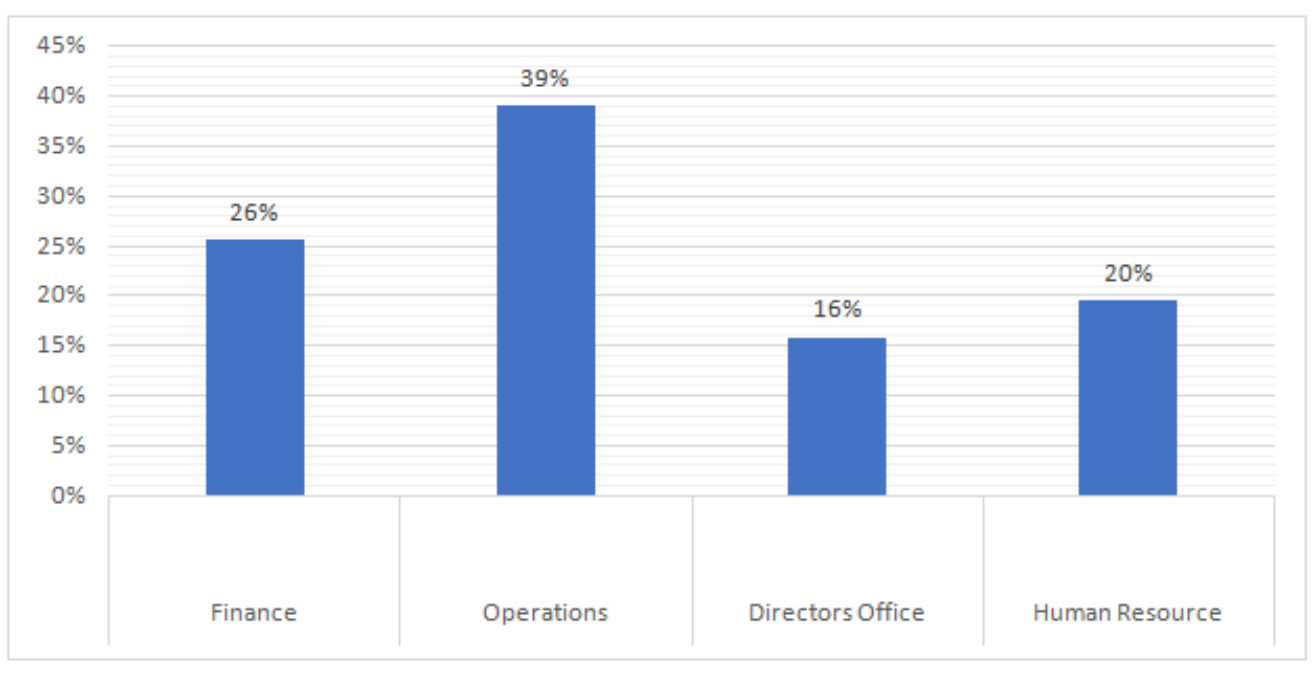

Figure4. 1. Work department

\section{Source; Research Findings 2020}

As shown, 39\% worked in operations department, $26 \%$ in finance department, $20 \%$ in human resource while $16 \%$ under the director's office. Therefore, the respondents were directly involved in the corporate governance and financial aspects of the SACCOs.

\subsection{Board independence}

The study sought to determine the influence of board independence on performance of deposit taking SACCOs in Kenya. To achieve this, a five point Likert Scale was applied. The findings of the study are shown by Table 4.2

Table4.2. Board independence

\begin{tabular}{|l|l|l|}
\hline Board Independence & Mean & Std Dev \\
\hline $\begin{array}{l}\text { Non-executive directors act independently and also control } \\
\text { stakeholders hence improving performance. }\end{array}$ & 2.83 & 0.3324 \\
\hline The chairman acts independently which enhances his/her authority & 3.60 & 0.6074 \\
\hline $\begin{array}{l}\text { The organization has a management board that has more than twice its } \\
\text { representation on the board of directors and not dominated by major } \\
\text { stakeholders }\end{array}$ & 3.32 & 0.4522 \\
\hline $\begin{array}{l}\text { The SACCO has an audit committee and it is chaired by an } \\
\text { independent director for mitigating financial risks. }\end{array}$ & 4.15 & 0.9841 \\
\hline $\begin{array}{l}\text { The company has a committee in charge of remunerations headed by } \\
\text { an independent director. }\end{array}$ & 3.66 & 0.6427 \\
\hline Nominations within the organization are conducted independently. & 4.01 & 0.8406 \\
\hline The SACCO outsources external auditors. & 3.66 & 0.6427 \\
\hline $\begin{array}{l}\text { Keen consultations are undertaken involving all board members prior } \\
\text { to any decision being made. }\end{array}$ & 3.98 & 0.8049 \\
\hline
\end{tabular}


Board Independence as an Antecedent for Firm Performance in the Context of Deposit Taking Savings and Credit Co-Operative Societies in Nairobi City County, Kenya

\begin{tabular}{|l|l|l|}
\hline The SACCO has representatives of large creditors of the company & 3.78 & 0.6711 \\
\hline $\begin{array}{l}\text { The independent members are free for any attachments or } \\
\text { commitments which may cloud their judgments during performing. }\end{array}$ & 3.20 & 0.4546 \\
\hline Average Score & $\mathbf{3 . 6 2}$ & $\mathbf{0 . 6 4 3 3}$ \\
\hline
\end{tabular}

\section{Source; Research Findings 2020}

As shown, the respondents indicated a large extent on the SACCO have an audit committee chaired by an independent director for mitigating financial risks and nominations within the organization are conducted independently having means of 4.15 and 4.01 respectively. A large extent was also indicated on keen consultations are undertaken involving all board members prior to any decision being made, the SACCO has representatives of large creditors of the company and, the SACCO outsources external auditors, with means of 3.98, 3.78 and 3.66 respectively. On the chairman acts independently which enhances his/her authority, the organization has a management board that has more than twice its representation on the board of directors and not dominated by major stakeholders and the independent members are free for any attachments or commitments which may cloud their judgments during performing a moderate extent was indicated with means of 3.60, 3.32, 3.66 and 3.20 respectively. Whereas on non-executive directors act independently and also control stakeholders hence improving performance, a small extent was indicated having a mean of 2.83. These findings imply that the respondents agreed that the board independence practices were of essence in their respective firms. On aggregate, the scores of mean and standard deviation were 3.62 and 0.6433 which confirm that these practices were adopted to a large extent in the Deposit Taking SACCOs.

\subsection{Organization Performance}

This section aimed at determining the performance of DTSs in Nairobi City County, Kenya. To achieve this, a five point Likert Scale was applied. The findings of the study are shown by Table 4.3 Additionally, financial performance was also sought from secondary sources including the financial statements and reports of the SACCOs.

Table4.3. Performance of Deposit Taking SACCOs

\begin{tabular}{|l|l|l|}
\hline Measure of performance & Mean & Std Dev \\
\hline Product quality & 3.75 & 0.9993 \\
\hline Employee satisfaction & 3.62 & 0.9731 \\
\hline New products & 3.71 & 0.8027 \\
\hline Satisfaction of members & 4.10 & 1.3219 \\
\hline Continuous organization improvement & 3.90 & 0.9674 \\
\hline Financial viability & 3.43 & 0.6081 \\
\hline Long term continuity & 3.74 & 0.5007 \\
\hline Speed of response & 3.32 & 0.9651 \\
\hline Average Score & $\mathbf{3 . 7 0}$ & $\mathbf{0 . 8 9 2 3}$ \\
\hline
\end{tabular}

\section{Source; Research Findings 2020}

As shown, the respondents indicated a large extent on Satisfaction of members, Continuous organization improvement, Product quality, Employee satisfaction and New Products Long term continuity with means of 4.10, 3.90,3.75, 3.62, 3.71 and 3.74 respectively. However, on Financial viability and Speed of response a moderate extent was indicated with means of 3.43 and 3.32. Data from the secondary sources further showed that over the study period, the performance of the DTSs measured using market share, members shares and output had increased moderately at an average of $15 \%$ within a five-year span.

\subsection{Correlation Analysis}

The researcher conducted a correlation analysis to determine the existence and intensity of the associations between board independence and performance of deposit taking SACCOs in Kenya.

Table4.4. Effect of board independence and performance of deposit taking SACCOs in Kenya.

\begin{tabular}{|l|l|l|}
\hline & & Performance of Deposit Taking SACCOs \\
\hline Board independence & Pearson Correlation & $0.333^{* *}$ \\
\hline & Sig. (2-tailed) & 0.0024 \\
\cline { 2 - 3 } & $\mathrm{N}$ & 82 \\
\hline
\end{tabular}


*. Correlation is significant at the 0.01 level (2-tailed).

The findings revealed that the correlation coefficient for board independence and performance was found to be 0.333 confirming that there was a moderate positive linear relationship between board independence and performance. This implies that an increase in board independence would have the associated effect of increasing performance of the DTSs.

\subsection{Regression Coefficient}

The study conducted a regression coefficient to establish the mean change in board independence for a unit change in the performance of deposit taking SACCOs in Kenya. The finding is shown in Table 4.5

Table4.5. Regression Coefficient

\begin{tabular}{|c|c|c|c|c|c|c|}
\hline \multirow{2}{*}{\multicolumn{2}{|c|}{ Model }} & \multicolumn{2}{|c|}{ Unstandardized Coefficients } & \multirow{2}{*}{\multicolumn{2}{|c|}{\begin{tabular}{|l|} 
Standardized Coefficients \\
Beta
\end{tabular}}} & \multirow[b]{2}{*}{ Sig. } \\
\hline & & B & Std. Error & & & \\
\hline & (Constant) & 0.563 & 0.236 & & 2.392 & 0.018 \\
\hline & Board Independence & 0.251 & 0.066 & 0.275 & 3.826 & 0.000 \\
\hline
\end{tabular}

Source: Researcher, 2020

The results illustrate a unit increase in board independence would result to 0.251 times increase in performance of deposit taking SACCOs in Kenya

$\mathrm{Y}=.563+0.251+\varepsilon$

The study found out that board Independence had a significant positive relationship with the performance of the deposit taking SACCOs $(\beta=0.251, \mathrm{P}=0.000)$. Hence a unit increase in the board independence will result in increase in the performance of the DTSs by a factor of 0.251 . This is because they will be able to make independent, efficient and firm decisions without any external influences. Similar findings were obtained by Ombaba, (2018) who investigated CG practices among SACCOs guided by the credit risk theory. According to the agency theory, well-functioning boards are a key functionality of organization in overseeing conduct and productivity of managers hence impact on organizational performance of the DTSs. Yet this tends to oppose Vasile (2013) who revealed that internal corporate governance negatively affected the performance of the Romanian banks.

Board independence was noted to be important in ensuring that the decisions made by the board were not in any way interfered or biased which my alter the efficiency. Board characteristics were indicated to be critical in ensuring that the board attains the deliverables. The respondents also unanimously agreed on the role played by board diversity in promoting inclusivity of board members from different backgrounds and gender. Further on board size, the respondents indicated that the size of the board was largely determined by firm size, firm age, leverage ratio and profitability. As such the board size should be proportional to the firm capabilities and the intended objectives. These corporate governance practices were postulated to monitor the performance in terms of cost and benefit analysis as well as assessment of financial sustainability.

\section{CONCLUSiOn AND RECOMmENDATIONS}

Based on the findings obtained the study makes various conclusions. The study found out that board independence has a strong influence on the performance of the Deposit Taking SACCOs. The study concludes that board independence affects the transparency, accountability and effectiveness of the decisions made by the board

The study found out that board independence had a positive effect on performance of the DTSs. The study recommends that firms should ensure that employees are committed to corporate governance characteristics by sharing information, providing relevant information to shareholders through disclosure of information especially financial reports and incorporating different activities of the board. This will ensure that the corporate governance measures are not only effectively implemented but also ensure maximum gains on performance. To enable generalization of the research findings, future researchers could consider carrying out a similar study in a different sector or sectors to assess any variation in responses and enable adequate comparisons to be made. 


\section{REFERENCES}

[1] Ahsan, M. K. (2016). Measuring financial performance based on CAMEL: A study on selected Islamic banks in Bangladesh. Asian Business Review, 6(1), 7-56.

[2] Ammar, A. A. (2017). Factors Influencing Intention to Adopt Mobile Banking in Sudanese Microfinance Sector (Doctoral dissertation, Multimedia University (Malaysia).

[3] Anyanga, W., \& Rotich, D. G. (2017). Effect of microeconomic factors on performance of listed commercial banks in Kenya. Strategic Journal.

[4] Barako, D. G., \& Brown, A. M. (2016). The corporate governance of the Kenyan public sector. In Corporate Governance in Africa (pp. 223-247). Palgrave Macmillan, London.

[5] Cooper, D. R., \& Schindler, P. S. (2012). Business research methods (9th Edition Ed.). New Delhi: Tata McGraw-Hill Publishing Company Limited.

[6] Creswell, J., (2003). Educational research planning, conducting and evaluating quantitative and qualitative research. New Jersey: Pearson

[7] David, P., \& Donaldson, K., (1993). Corporate Governance, Family Ownership and Firm Value: the Canadian evidence.

[8] Duncan, N. M., Njeru, A., \& Tirimba, O. I. (2015). Effect of loan repayment on financial performance of deposit taking Savings and credit societies in Mount Kenya Region. International Journal of Innovation and Applied Studies, 10(4), 1238.

[9] Elyasiani, E., \& Jia, J. J. (2019). Relative performance and systemic risk contributions of small and large banks during the financial crisis. The Quarterly Review of Economics and Finance.

[10] Hargovan, A., \& Harris, J. (2018). Principles of contemporary corporate governance. Cambridge University Press.

[11] Heale, R., \& Twycross, A. (2015). Validity and reliability in quantitative studies. Evidence-based nursing, 18(3), 66-67.

[12] Iyikirenga, M. R. (2014). Umurenge SACCO As A Tool For Financial Inclusion: A Case Study Of Nyaruguru District (Doctoral dissertation, Mount Kenya University).

[13] Johnson, G., Whittington, R., Scholes, K., Angwin, D., \& Regnér, P. (2014). Exploring Strategy. Harlow.Financial Times Prentice Hall.

[14] Kakabadse, N. K., Yang, H., \& Sanders, R. (2010). The effectiveness of non-executive directors in Chinese state-owned enterprises. Management Decision, 48(7), 1063-1079.

[15] Karuma, L. M. (2017). Effect of Corporate Governance on Performance of Tea Factories Managed By Kenya Tea Development Agency (Doctoral dissertation).

[16] Keben, T. K., \& Maina, K. E. (2018). Effect of liquidity risk management on financial performance of deposit taking SACCOs in Uasin Gishu County, Kenya. International Academic Journal of Economics and Finance, 3(2), 323-335.

[17] Kenani, I. M., \& Bett, S. (2018). Corporate governance and performance of savings and credit cooperative societies in Kisii County, Kenya. International Academic Journal of Human Resource and Business Administration, 3(4), 101-123.

[18] Kitur, T. \& Kinyua, G. M. (2020). An Empirical Analysis of the Relationship between Resource Fluidity and Firm Performance: A Perspective of Tours and Travel Companies in Kenya. International Journal of Innovative Research and Advanced Studies, 7(11): 13 - 21.

[19] Lincolin, A., (2015). An Assessment of Microfinance Institution Performance: The Importance of Institutional Environment, GadjahMada International Journal of Business, 7(3) 391-427.

[20] Lohr, S. L. (2019). Sampling: Design and Analysis: Design and Analysis. Chapman and Hall/CRC.

[21] Magali, J. J., \& Lang'at, J. (2014). Impacts of Corporate Governance on Efficiency and Sustainability of the Best Rural Saccos in Tanzania. Global Journal of Commerce Ad Management Perspective, 3(2), 1-8.

[22] Matanda, J., (2016). Relationship Between Corporate Governance And Performance Of Commercial Banks In Kenya. Unpublished MBA Project, JKUAT.

[23] Mbai, W., Kinyua, G., \& Muhoho, J. (2018). Corporate Leadership and Performance of Machakos Water and Sewerage Company in Kenya. The Strategic Journal of Business \& Change Management, 5(3), 631639.

[24] Mbaire, (2017). Role of Human Resource Management practices on employee commitment at ILRI. Unpublished MBA Project, USIU.

[25] Mbugua, J. W. \& Kinyua, G. M. (2020). Service Differentiation and Organization Performance: An Empirical Analysis of Deposit Taking SACCOs in Nairobi City County, Kenya. Journal of Business and Economic Development, 5(2): 64-72. 
[26] Mensah, J., \& Maponga, S. (2017). Balance Scorecard: A Standard Tool to Measure Performance in Private Universities in Botswana. Balance, 8(19).

[27] Mugambi, L. M. \& Kinyua, G. M. (2020). Role of Innovation Capability on firm performance in the context of Commercial Banks in Nairobi City County, Kenya. International Journal of Current Aspects in Finance, Banking and Accounting, 2(3): $14-23$.

[28] Mugenda, M., \& Mugenda, G., (2008). Research methods: Quantitative and Qualitative Approaches. Nairobi, Kenya: ACTS Press.

[29] Mumanyi, E. A. L. (2014). Challenges and opportunities facing Savings and credit societies in the current devolved system of government of Kenya: A case study of Mombasa County. International Journal of Social Sciences and Entrepreneurship, 1(9), 288-314.

[30] Murerwa, B. M. \& Kinyua, G. M. (2021). Analysis of the Role of Competitive Benchmarking on Service Delivery in Multinational Pharmaceutical Companies in Nairobi City County, Kenya. International Journal of Managerial Studies and Research, 9(7): 1-9.

[31] Muvuna, M. (2017). Impact of credit on welfare improvement in Rwanda: case study: Koruteganya umurenge SACCO of Nyamabuye (Doctoral dissertation, University of Rwanda).

[32] Njenga, R., \& Jagongo, A. (2019). Effect of financial management decisions on financial performance of selected deposit taking Savings and credit societies in Kiambu County, Kenya: Theoretical review. International Academic Journal of Economics and Finance, 3(3), 204-217.

[33] Ogega, O.D., (2014). The Effect of Ownership structure on the financial Performance of Commercial Banks in Kenya. Unpublished MBA project, University of Nairobi.

[34] Oketch, J. O., Kilika, J. M. \& Kinyua, G. M. (2020). Top Management Team Cognitive Characteristics and Organizational Performance. Journal of Business and Management, 22 (2): 22-30.

[35] Ombaba, B. M. K., (2018). Effect of Risk Management on Corporate Governance in Saccos in Nairobi County- Kenya. International Journal of Finance Accounting and Economics (IJFAE) 1 (1), 25-35.

[36] Omwenga, J. (2019). The effect of Corporate Governance on Financial Performance of Large Tier Savings and Credit Cooperatives Societies in Kenya.

[37] Ong'esa, S. O. \& Kinyua, G. M. (2020). Effect of Operational Capability on Performance of Air Kenya Express Limited in Nairobi City County, Kenya. International Journal of Managerial Studies and Research, 8((9): 1-11.

[38] Oseno, B. (2019). The moderating effect of legal factors on the relationship between strategic leadership practices and performance of deposit taking SACCOs in Kenya. The Strategic Journal of Business \& Change Management, 6(4), 1049-1063.

[39] Otieno, K., Mugo, R., Njeje, D., \& Kimathi, A. (2015). Effect of corporate governance on financial performance of Savings and Credit Societies in Kenya. Research Journal of Finance and Accounting, 6(2), 48-58.

[40] Vasile, F. (2013). The Relationship between Corporate Governance Practices and Financial Performance of Savings and credit societies in Murang'a County. Unpublished MBA Project, University of Nairobi.

[41] Wanjiku, M. M., Kinyua, G. \& Kahuthia, J. (2020). Effect of Strategic Intent on Firm Performance in the Context of Safaricom Limited in Kenya. International Academic Journal of Human Resource and Business Administration, 3(8), 194-206.

\section{AUTHORS' BIOGRAPHY}

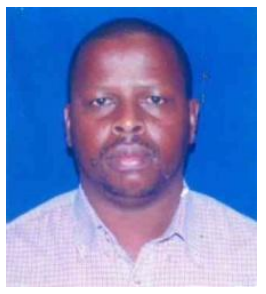

Zephaniah C Chesire, is the head of Finance at Tembo Savings and credit cooperative Society. He holds a Bachelor of Commerce in Finance from Catholic University of Eastern Africa and is currently pursuing a Master of Business Administration in strategic Management of Kenyatta University. He is a certified Public Accountant of Kenya. His area of interest in research is in corporate governance.

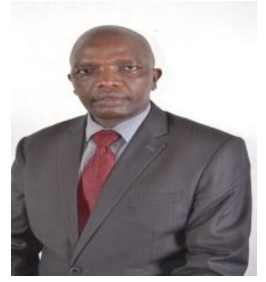

Dr. Godfrey M. Kinyua, is a lecturer in the Department of Business Administration, School of Business of Kenyatta University. He holds a Doctor of Philosophy in Business Administration from Kenyatta University, Master of Business Administration from the University of Nairobi and Bachelor of Education from Egerton University. His key areas of interest in research includes knowledge 
Board Independence as an Antecedent for Firm Performance in the Context of Deposit Taking Savings and Credit Co-Operative Societies in Nairobi City County, Kenya

management, competitive intelligence and green innovation.

Citation: Zephaniah C. Chesire, Dr Godfrey Kinyua. "Board Independence as an Antecedent for Firm Performance in the Context of Deposit Taking Savings and Credit Co-Operative Societies in Nairobi City County, Kenya" International Journal of Managerial Studies and Research (IJMSR), vol 9, no. 8, 2021, pp. 5464. doi: https://doi.org/10.20431/2349-0349.0908007.

Copyright: () 2021 Authors. This is an open-access article distributed under the terms of the Creative Commons Attribution License, which permits unrestricted use, distribution, and reproduction in any medium, provided the original author and source are credited. 